\title{
A supercritical tuneable process for the selective extraction of fats and essential oil from coriander seeds
}

\author{
Houcine Mhemdi ${ }^{\mathrm{a}, \mathrm{b}}$, Elisabeth Rodier ${ }^{\mathrm{a}}$, Nabil Kechaou ${ }^{\mathrm{b}}$, Jacques Fages ${ }^{\mathrm{a}, *}$ \\ ${ }^{a}$ Université de Toulouse, Ecole des Mines Albi, RAPSODEE Centre, CNRS, F-81013 Albi, France \\ ${ }^{\mathrm{b}}$ Université de Sfax, Ecole Nationale d'Ingénieurs de Sfax, Groupe de Recherche en Génie des Procédés Agroalimentaire, Unit MFAM, 02/UR/11-02, 3038 Sfax, Tunisia
}

\begin{abstract}
A B S T R A C T
A selective supercritical $\mathrm{CO}_{2}$ extraction process has been developed in order to extract selectively the veg etal oil and the essential oil from coriander seeds in a consecutive way by tuning experimental condi tions. A 4 step process has been set up: (i) seeds preparation by grinding and sieving, (ii) extraction by supercritical $\mathrm{CO}_{2}$ and (iii; iv) selective separation in two separators with different pressure levels. The first part of this study consisted in studying the effects of the operating conditions $\left(\mathrm{T}, \mathrm{P}, \mathrm{CO}_{2}\right.$ density, flow rate and particle size distribution of ground seeds) on the yield of extraction. The results showed that the global performance of the process depends mainly on the pressure level of extraction, on the $\mathrm{CO}_{2}$ flow rate and on the size of the ground seeds. An optimization of the parameters led to an extraction ratio of $90 \%$. The second part of this study dealt with the effects of the operating conditions on the quality of extracts, and more precisely on their composition in vegetal oil and essential oil. It was observed that the supercritical extraction had no major effect on the fatty acid composition of the vegetal oil compared to classical extraction techniques, while essential oil is enriched in components such as linalool and that a previous drying of the seeds is deleterious. Finally, we propose a procedure in order to extract separately each oil by adjusting $\mathrm{CO}_{2}$ density and separation conditions.
\end{abstract}

\section{Introduction}

Coriander (Coriandrum sativum L.) is an annual Apiaceae (Umbel liferae) herb, which is widely used in food (Aluko et al., 2001; Burdok and Carabin, 2009), pharmaceutical (Jabeen et al., 2009) and cosmetic (Eyres et al., 2005) industries.

Coriander fruits contain vegetal oil (VO) with a high concentra tion of monounsaturated fatty acids, especially of petroselinic acid (C18:1 cis $\Delta^{6}$ ). This acid can be oxidatively cleaved to produce a mixture of lauric acid (C12:0), a compound useful in the produc tion of detergents, and adipic acid, a C6 dicarboxylic acid, which can be utilized in the synthesis of nylon polymer (Msaada et al., 2009b). Moreover, the essential oil (EO) of coriander has been shown to have antibacterial (Kubo et al., 2004; Matasyoh et al., 2009), antioxidant (Wangensteen et al., 2004), antidiabetic

Abbreviations: Bi, Biot number; $d$, diameter $(\mathrm{m})$; $D$, diffusivity $\left(\mathrm{m}^{2} / \mathrm{s}\right)$; EO, essential Oil; ER, extraction ratio (\%); EY, extraction yield (\%); FA, fatty acid; $K$, mass transfer coefficient $(\mathrm{m} / \mathrm{s}) ; m$, mass of the extract $(\mathrm{g})$; MUFA, monounsaturated fatty acid; $P$, pressure (Pa); PUFA, polyunsaturated fatty acid; $Q$ flow rate of $\mathrm{CO}_{2}(\mathrm{~kg} / \mathrm{h}$ ); FA, saturated fatty acid; $T$, temperature $\left({ }^{\circ} \mathrm{C}\right)$; VO, vegetal oil; $\rho, \mathrm{CO}_{2}$ density $\left(\mathrm{kg} / \mathrm{m}^{3}\right)$; $\sigma$, standard deviation.

* Corresponding author. Tel.: +33 (0)5 63493 141; fax: +33 (0)5 63493025 .

E-mail address: jacques.fages@mines-albi.fr (J. Fages).
(Gallagher et al., 2003), anticancerous and antimutagenic (Chithra and Leelamma, 2000) activities.

There are three major extraction techniques used to obtain VO and EO from coriander seeds, which are steam distillation, organic solvent extraction (Soxhlet), and supercritical fluid extraction. Each technique has its benefits and drawbacks as far as operating cost, capital cost, yield and quality of the extracts are concerned. Steam distillation is by far the most widely used and the cheapest way of extraction, but it is limited to EO production, and it may induce chemical changes in the extract by oxidation of some compounds (Anitescu et al., 1997; Donelian et al., 2009; Msaada et al., 2007). Organic solvent extraction is intermediate in capital and operating cost, and is used for producing VO from oilseeds. However, con cerns about the solvent residues in the oleoresin products, the new regulations of volatile organic solvent emissions in the air, and the extent of further refining that is required after the extrac tion step restrain the use of this technology (Catchpole and Grey, 1996). Supercritical fluid extraction is the most recent technology that is of increasing importance in the production of EO, VO, and a range of other substances from natural products (Brunner, 2005; Mohamed and Mansoori, 2002; Temelli, 2009). This tech nique has the highest capital cost of the three techniques, and moderate operating costs. However, neither solvent residues re main in the product after extraction, nor there are any chemical 
changes due to the processing technique, which gives extract of outstanding quality (Boutin and Badens, 2009; Brunner, 2005; Catchpole and Grey, 1996; Machmudah et al., 2008; Donelian et al., 2009; Perrut and Clavier, 2003).

The review of literature shows that most of the research works related to the extraction of coriander seeds are aimed at extracting either the VO (Msaada et al., 2009a,b) or the EO (Bandoni et al. 1998; Grosso et al., 2008; Illés et al., 2000; Msaada et al., 2007). The aim of this work is to put forward a new process using super critical carbon dioxide, which is able to extract selectively the VO and the EO in a consecutive way by tuning experimental condi tions. The effects of operating conditions on the yield of extraction and on the quality of extracts will be also studied to optimize the process.

\section{Materials and methods}

\subsection{Raw material}

Coriander seeds came from Canada and were provided by the laboratory of General Herbalism, Marseille, France. The seeds used were mature and brown. They were stored in a refrigerator at $4{ }^{\circ} \mathrm{C}$ before use. The moisture content was about $10 \%$. Their mass con tent of VO and EO, respectively determined by Soxhlet and steam distillation were $20.8 \%(\mathrm{w} / \mathrm{w})$ of $\mathrm{VO}$ and $0.4 \%(\mathrm{w} / \mathrm{w})$ of EO. Hence, EO represents $1.9 \%(\mathrm{w} / \mathrm{w})$ of the total oil content. The crushed cori ander seeds (mean size $0.3 \mathrm{~mm}$ ) were used for Soxhlet and steam distillation extraction of EO and VO. The extraction was carried for a long time ( $6 \mathrm{~h}$ for $\mathrm{VO}$ extraction and $90 \mathrm{~min}$ for EO extraction) to ensure total oil extraction. The supercritical extraction fluid was carbon dioxide (purity 99.995\%, w/w) purchased from Air liquide S.A., Paris, France.

\subsection{Particle size reduction}

In mature coriander seeds, the oil is homogeneously distributed and it is bounded by cell membranes. Crushing the seeds may damage some cell membranes leading to the release of some oil and facilitating the extraction step. To study the effect of particle size on the extraction ratio, coriander seeds were first crushed. The grinding was performed using a grinder type IKA M20. The particle size distribution of ground seeds was determined by siev ing. Size fractions were then obtained using sieves with an aper ture size of $200 \mu \mathrm{m}, 400 \mu \mathrm{m}, 630 \mu \mathrm{m}, 800 \mu \mathrm{m}$ and $1 \mathrm{~mm}$ Afterwards, three different fractions were used for extraction, hav ing a mean size of $0.3 \mathrm{~mm}, 0.515 \mathrm{~mm}$ (named 0.5 in the following sections) and $0.9 \mathrm{~mm}$.

\subsection{Experimental set up and protocol for extraction}

Supercritical $\mathrm{CO}_{2}$ extraction experiments on coriander seeds were carried out on the pilot scale apparatus (Separex, France) shown schematically in Fig. 1. The mass of ground and sieved cori ander seeds used in each experiment was approximately $50 \mathrm{~g}$.

The pilot scale tests were performed by flowing carbon dioxide at the required temperature and pressure through a bed of ground coriander contained in the extractor (8). A backpressure regulator controlled the pressure in the extractor and temperature was reg ulated by an electrical device. The carbon dioxide and dissolved solute was then depressurized causing desaturation and condensa tion of VO into the first cyclonic separator (S1), which was held at a pressure of $7 \mathrm{MPa}$ and a temperature of $30^{\circ} \mathrm{C}$. Then carbon dioxide flowed through a needle valve causing desaturation and condensa tion of the remaining EO and water into the second cyclonic sepa rator (S2). This last vessel was maintained at a pressure of $4 \mathrm{MPa}$ and a temperature of $10^{\circ} \mathrm{C}$. After the extraction step, a yellow $\mathrm{VO}$, was recovered in separator 1 (S1) and a fragrant EO is collected in separator 2 (S2). Extracts were sampled every $15 \mathrm{~min}$ from the separation vessels in order to follow the kinetics of extraction. The experiment was stopped when the amount extracted re mained constant (i.e. once the derivative of the mass of extract in function of time, $\mathrm{dm} / \mathrm{dt}$, was lower than $0.005 \mathrm{~g} / \mathrm{min}$ ) and a pla teau was reached on the extraction kinetics.

\subsection{Chromatographic analysis}

\subsubsection{Fatty acid composition of vegetal oil}

The fatty acid composition of the coriander VO was determined by analysis of their methyl esters obtained by transesterification. These esters were analyzed using a gas chromatograph type Varian CP select CB 3900 equipped with a silica capillary column ( $50 \mathrm{~m} \times 0.25 \mathrm{~mm} \times 0.25 \mu \mathrm{m})$. Temperature was held at $185^{\circ} \mathrm{C}$ for $4 \mathrm{~min}$, raised to $250^{\circ} \mathrm{C}$ at $15^{\circ} \mathrm{C} / \mathrm{min}$. The injection and the detector temperatures were both $250^{\circ} \mathrm{C}$. The carrier gas was $\mathrm{H}_{2}(1.2 \mathrm{~mL} /$ $\mathrm{min}$ ). The device was equipped with a FID detector (lowest detect able quantity: $5 \mathrm{pg}$ of $\mathrm{C}$ ), which gave the chromatogram for each sample. The identification of fatty acids was made by comparing their retention times with those of standard samples. Their mass content was calculated by assuming that the total peaks area ac count for $100 \%$ of the constituents.

\subsubsection{Composition of essential oil}

The separation of volatile components of the coriander EO was performed using a gas chromatograph capillary type HP 5890 ser ies II, equipped with a DB 5 MS column $(30 \mathrm{~m} \times 0.25 \mathrm{~mm} \times$ $0.25 \mu \mathrm{m}$ ), a detector of flame ionization (FID) and injector EPC (electronic pressure control). The tests were conducted according to the following conditions. The column was held at $40^{\circ} \mathrm{C}$ for $5 \mathrm{~min}$ and then increased at $5^{\circ} \mathrm{C} / \mathrm{min}$ up to $280^{\circ} \mathrm{C}$ over $53 \mathrm{~min}$. The solvent was dichloromethane and the flow through the column was $1.3 \mathrm{~mL} / \mathrm{min}$. The FID detector was held at $300{ }^{\circ} \mathrm{C}$. The head pressure of the column was $0.1 \mathrm{MPa}$ and the amount injected was $0.5 \mu \mathrm{L}$. The identification of the different components of EO was made by calculating the retention index and Kovats index and by comparing them with those of the literature.

\subsection{Theory and calculation}

\subsubsection{Extraction yield and extraction ratio}

In this study, the extraction yield (EY) is defined as the total mass of extract recovered from $100 \mathrm{~g}$ of coriander. It is expressed in\% ( $g$ of extract $/ 100 \mathrm{~g}$ coriander). The extraction ratio (ER) is the ratio in mass percent of oil extracted over the total quantity of oil contained in the seeds of coriander.

\subsubsection{Mass transfer parameters}

The supercritical fluid extraction implies the mass transfer of the $\mathrm{VO}$ and EO from coriander seeds to the flowing carbon dioxide. It is then important to understand this phenomenon and to appre ciate its extent. This requires to estimate the parameters associated to mass transfer, such as the diffusivity of the components to be extracted, D, resulting from the diffusive internal transfer inside the seeds, the mass transfer coefficient, $\mathrm{K}$, resulting from the con vective transfer at the seeds surface and the Biot number, $\mathrm{Bi}$, com paring both transfers.

The model used in this work to describe supercritical carbon dioxide extraction of oils from coriander seeds was developed by Goto et al. $(1993,1994)$. It is applicable to both essential and veg etal oil. This model considers coriander seeds like a porous solid containing EO associated with lipids located in vesicles (subse quent pores when opened). Internal mass transfer of oils implies 


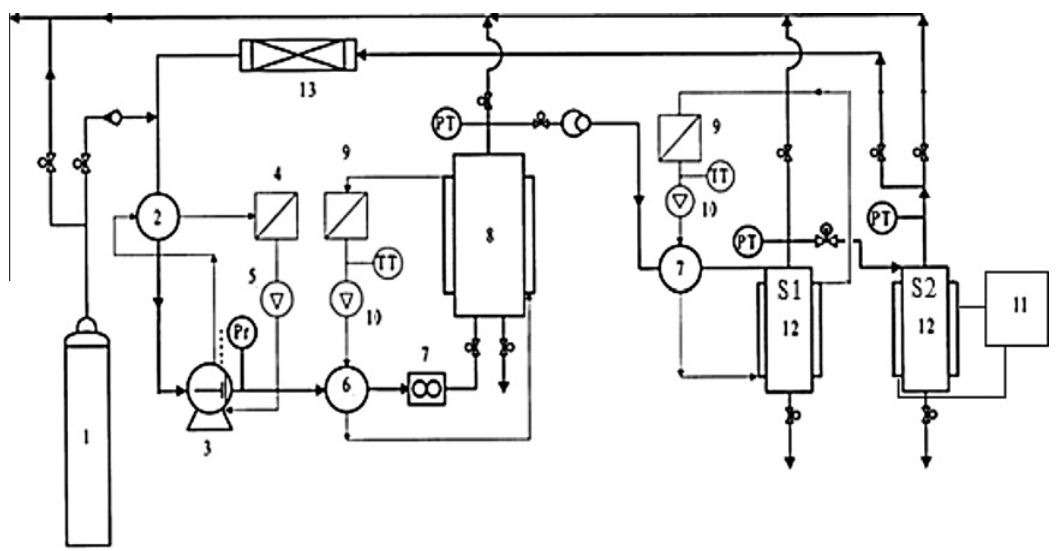

Fig. 1. Pilot scale extraction apparatus. $1-\mathrm{CO}_{2}$ cylinder; 2 - condenser; 3 - $\mathrm{CO}_{2}$ pump; 4 - refrigerator tank; 5 - refrigerator pump; 6 - heaters; 7 - mass flow meter; 8 extractor; 9 - heating baths; 10 - pumps of heating systems; 11 - cooling bath; 12 - separators (S1 and S2); 13 - filter; Pr - pressostat; PT - pressure transmitter; TT temperature transmitter.

a desorption of the molecules from the pores walls, internal diffu sion through fluid inside the pores and a convective transfer at the seeds surface through the supercritical rich phase to be carried away by bulk flow. The adsorption desorption equilibrium is sup posed to be established instantaneously. In addition, the solute concentration at the contacting surface between pores outlet (at the seeds surface) and surrounding $\mathrm{CO}_{2}$ is unknown. The following assumptions have been made: no axial or radial dispersion, con stant solvent density and constant flow rate through the bed. Ex tracted oils are considered as the major components of coriander seeds and both VO and EO are considered here as pure components.

2.5.2.1. Diffusivity $D$. To calculate the diffusion coefficient $D$ of ex tracted oils in the coriander seeds, we used a mathematical model developed by Goto et al. (1993). This model gives a relationship be tween experimental extraction ratio and the extraction time and it allows the estimation of the effective diffusivity from experimental data. It has already been successfully applied by Catchpole and Grey (1996) to determine the values of diffusivity of oil through coriander seeds during supercritical $\mathrm{CO}_{2}$ extraction. The relation ship is as follows:

$$
\operatorname{Ln}(1 \quad \text { ERt } / 100) \quad 15 D t / r^{2}
$$

Here ERt is the extraction ratio at time $t, r$ is the radius of cori ander particles and $D$ is the diffusivity. The slope of the curve Ln (1 ERt/100) versus $t$ allows calculating the diffusivity.

2.5.2.2. Mass transfer coefficient $K$. The coefficient of external mass transfer $(K)$ has been calculated by applying a correlation described by Brunner (1994). This correlation links the dimensionless num bers of Schmidt (Sc), Reynolds ( $\mathrm{Re}$ ) and Sherwood (Sh) and it is applicable for the extraction of oilseeds for $3<\operatorname{Re}<3000$.

Sh $2+1.1 \mathrm{Sc}^{1 / 3} \operatorname{Re}^{0.6}$

2.5.2.3. Biot number Bi. The Biot number (Bi) is a dimensionless number used for either heat or mass, internal and external trans fers comparison. It is calculated by using relation 3 :

Bi $K d / D$

Here $K$ is the mass transfer coefficient, $d$ the diameter of corian der particles and $D$ the diffusivity.

\subsubsection{Residence time}

The residence time is the time taken by the $\mathrm{CO}_{2}$ to flow through the bed of coriander. It is equal to the total coriander bed volume divided by the volumetric flow rate of carbon dioxide under extrac tion conditions.

\subsection{Statistical analysis}

To study the effects of particle size, flow rate, pressure, temper ature and $\mathrm{CO}_{2}$ density on the extraction ratio, the Fisher's least sig nificant difference (LSD) test was applied. Each experiment was repeated thrice $(1,1 \mathrm{a}$ and $1 \mathrm{~b})$. Means and standard deviations were calculated (Table 2). Statistical analyses were carried out using the software Statgraphics ${ }^{\circledR}$ Plus 5.1 (Statpoint TechnologiesInc, USA) and for each analysis, significant level of $5 \%$ was assumed.

\section{Results and discussion}

\subsection{Operating conditions and reproducibility of the results}

Different operating conditions were used to study the influence of the pressure, the temperature, the density and the flow rate of $\mathrm{CO}_{2}$ and the mean particle size of ground seeds to be processed on the extraction ratio and the composition of the extract. The tested operating conditions are gathered in Table 1. Experiment 9 is similar to experiment 1 , except that seeds were previously dried at $70^{\circ} \mathrm{C}$ and $60 \mathrm{kPa}$ for $24 \mathrm{~h}$.

Results of extraction ratio and mass transfer characteristics are gathered in Table 2. Three experiments were performed using the same experimental conditions, which are experiment $1 \mathrm{a}, 1 \mathrm{~b}$ and 1 c. The extraction ratios result in a mean value of $0.845 \pm 0.016$. Statistical analysis shows that there is no significant difference at the $5 \%$ error level. In addition, the evolution of the weight of ex tract with time is similar for the three experiments. Hence, the reproducibility is satisfying.

\subsection{Effect of the operating conditions on extraction yield}

\subsubsection{Influence of the particle size}

The study of the effect of the particle size on the extraction ratio (Fig. 2 and Table 2) shows that reducing the particle size from $0.9 \mathrm{~mm}$ (experiment 3 in Table 1) to $0.5 \mathrm{~mm}$ (experiment 1 in Ta ble 1 ) improves significantly the extraction ratio from $31 \%$ to $85 \%$. 
Table 1

Supercritical fluid extraction experiments: operating conditions.

\begin{tabular}{lllllll}
\hline \multicolumn{2}{l}{ Operating conditions } & & & & \\
\hline Experiment & \multicolumn{2}{l}{ Extractor } & & $\begin{array}{l}Q \mathrm{CO}_{2} \\
(\mathrm{~kg} / \mathrm{h})\end{array}$ & $d(\mathrm{~mm})$ & $\begin{array}{l}\text { Extraction } \\
\text { time (min) }\end{array}$ \\
\cline { 2 - 6 } & $\begin{array}{l}P \\
(\mathrm{MPa})\end{array}$ & $\begin{array}{l}T \\
\left({ }^{\circ} \mathrm{C}\right)\end{array}$ & $\begin{array}{l}\rho \mathrm{CO}_{2} \\
\left(\mathrm{~kg} / \mathrm{m}^{3}\right)\end{array}$ & & & \\
\hline $1 \mathrm{a} ; 1 \mathrm{~b} ; 1 \mathrm{c}^{*}$ & 21 & 35 & 873.67 & 1 & 0.5 & 300 \\
2 & 10 & 35 & 712.81 & 1 & 0.5 & 330 \\
3 & 21 & 35 & 873.67 & 1 & 0.9 & 300 \\
4 & 21 & 35 & 873.67 & 1 & 0.3 & 300 \\
5 & 21 & 45 & 822.91 & 1 & 0.3 & 300 \\
6 & 21 & 55 & 767.88 & 1 & 0.3 & 300 \\
7 & 21 & 35 & 873.67 & 1.5 & 0.3 & 300 \\
8 & 21 & 35 & 873.67 & 2 & 0.3 & 300 \\
$9^{* *}$ & 21 & 35 & 873.67 & 1 & 0.5 & 300 \\
$10 \alpha^{* * *}$ & 8 & 35 & 419.09 & 1 & 0.5 & 60 \\
$10 \beta^{* * *}$ & 21 & & 873.67 & & & 240 \\
\hline
\end{tabular}

Experiments 1a, 1b and 1c were performed using the same experimental conditions in order to test the reproducibility of results.

** Experiment 9 was performed in the same experimental conditions as experiment 1 , except that the seeds were previously dried at $70^{\circ} \mathrm{C}$ and $60 \mathrm{kPa}$ for $24 \mathrm{~h}$.

*** Experiment 10 was performed in two steps with 2 pressure levels: first step $(10 \alpha)$ at $8 \mathrm{MPa}$ for $60 \mathrm{~min}$ and then step $2(10 \beta)$ at $21 \mathrm{MPa}$ for $240 \mathrm{~min}$.

Table 2

Supercritical fluid extraction experiments: extraction ratio, statistical analysis and mass transfer parameters.

\begin{tabular}{|c|c|c|c|c|c|c|}
\hline \multicolumn{7}{|l|}{ Results } \\
\hline \multirow[t]{2}{*}{ Experiment } & \multicolumn{3}{|c|}{ Statistical analysis } & \multirow{2}{*}{$\begin{array}{l}D\left(\mathrm{~m}^{2} / \mathrm{s}\right) \\
\left(10^{13}\right)\end{array}$} & \multirow{2}{*}{$\begin{array}{l}K(\mathrm{~m} / \mathrm{s}) \\
\left(10^{5}\right)\end{array}$} & \multirow{2}{*}{$\begin{array}{l}\mathrm{Bi} \\
\left(10^{5}\right)\end{array}$} \\
\hline & $\begin{array}{l}\text { ER } \\
(\%)\end{array}$ & $\sigma$ & $\begin{array}{l}\text { LSD } \\
\text { tests }\end{array}$ & & & \\
\hline 1 & 84.5 & 1.6 & a & 1 & & \\
\hline 2 & 23.5 & 0.45 & b & 0.5 & & \\
\hline 3 & 31.3 & 0.6 & c & 0.1 & & \\
\hline 4 & 88.3 & 1.9 & $\mathrm{a}, \mathrm{d}$ & 1.1 & 4.8 & 1.31 \\
\hline 5 & 91.5 & 1.8 & d & & & \\
\hline 6 & 90.0 & 1.7 & d & & & \\
\hline 7 & 72.6 & 1.4 & e & & 5.6 & 11.8 \\
\hline 8 & 61.1 & 1.2 & f & & 6.3 & 14.4 \\
\hline 9 & 80.0 & 1.2 & $\mathrm{~g}$ & & & \\
\hline $10 \alpha$ & 2.0 & 0.1 & $\mathrm{~h}$ & & & \\
\hline $10 \beta$ & 82.0 & 1.5 & $\mathrm{a}, \mathrm{g}$ & & & \\
\hline
\end{tabular}

*a, b, c, d, e, f, g and h means that experiments with the same superscript letters were not significantly different while those with different superscript letters are significantly different (LSD test, $5 \%$ level).

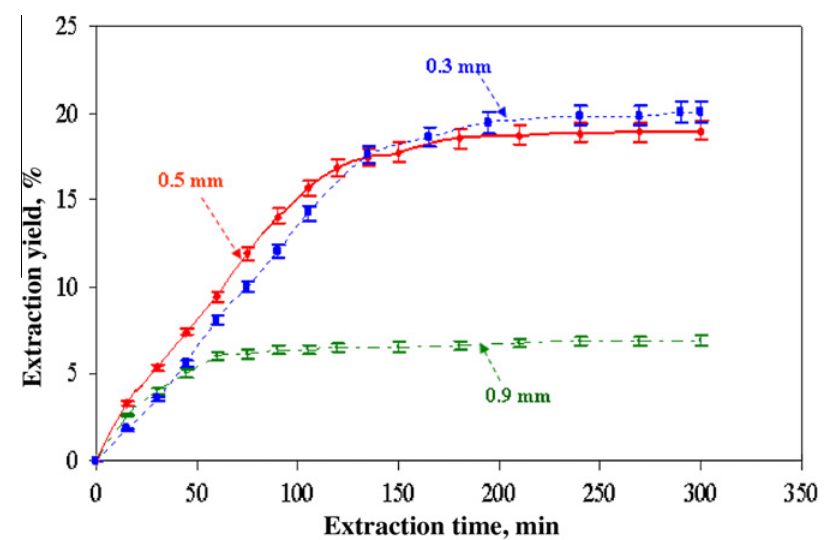

Fig. 2. Effect of particle size on the extraction yield in function of time for $P=21 \mathrm{MPa}, T=35^{\circ} \mathrm{C}$ and $Q=1 \mathrm{~kg} / \mathrm{h}$.

This behavior can be attributed to the increase of the contacting area and to the decrease of the mass transfer limitations. Measure ments of the specific surface area have been performed applying the BET method to a krypton adsorption isotherm. They have led to values of $0.13 \mathrm{~m}^{2} / \mathrm{g}$ and $0.65 \mathrm{~m}^{2} / \mathrm{g}$, respectively for $0.9 \mathrm{~mm}$ and $0.5 \mathrm{~mm}$ particle size fraction, which confirm the change in specific surface area with particle size. Similarly, the effective diffusivity is estimated to be $10^{13} \mathrm{~m}^{2} / \mathrm{s}$ for a mean particle size of $0.5 \mathrm{~mm}$ while for a diameter of $0.9 \mathrm{~mm}$ it is 10 times smaller at $0.1 \times 10^{13} \mathrm{~m}^{2} / \mathrm{s}$. These results are similar to those obtained by Catchpole and Grey (1996) and Grosso et al. (2008).

Increasing the extraction ratio when the particle size decreases may be also attributed to the modification of the internal structure of coriander seeds after grinding. Indeed, the oils are stored inside vesicles. After grinding, these vesicles may be damaged leading to a faster release of the oils. So, the more the vesicles are damaged, the more accessible they are for carbon dioxide leading to a higher extraction yield. Scanning electron microscope images of ground coriander seeds before (Fig. 3A) and after (Fig. 3B) supercritical extraction show holes on the particle surface after extraction that are not present before extraction. In addition, reducing the size fraction of ground seeds from $0.5 \mathrm{~mm}$ (experiment 1 in Table 1 ) to $0.3 \mathrm{~mm}$ (experiment 4 in Table 1) slightly influences the extrac tion ratio which increases from $85 \%$ to $88 \%$.

\subsubsection{Influence of flow rate}

To study the effect of solvent flow rate on extraction efficiency, three extraction tests were performed under the same operating conditions with three different flow rates of $\mathrm{CO}_{2}: 1 \mathrm{~kg} / \mathrm{h}, 1.5 \mathrm{~kg} / \mathrm{h}$
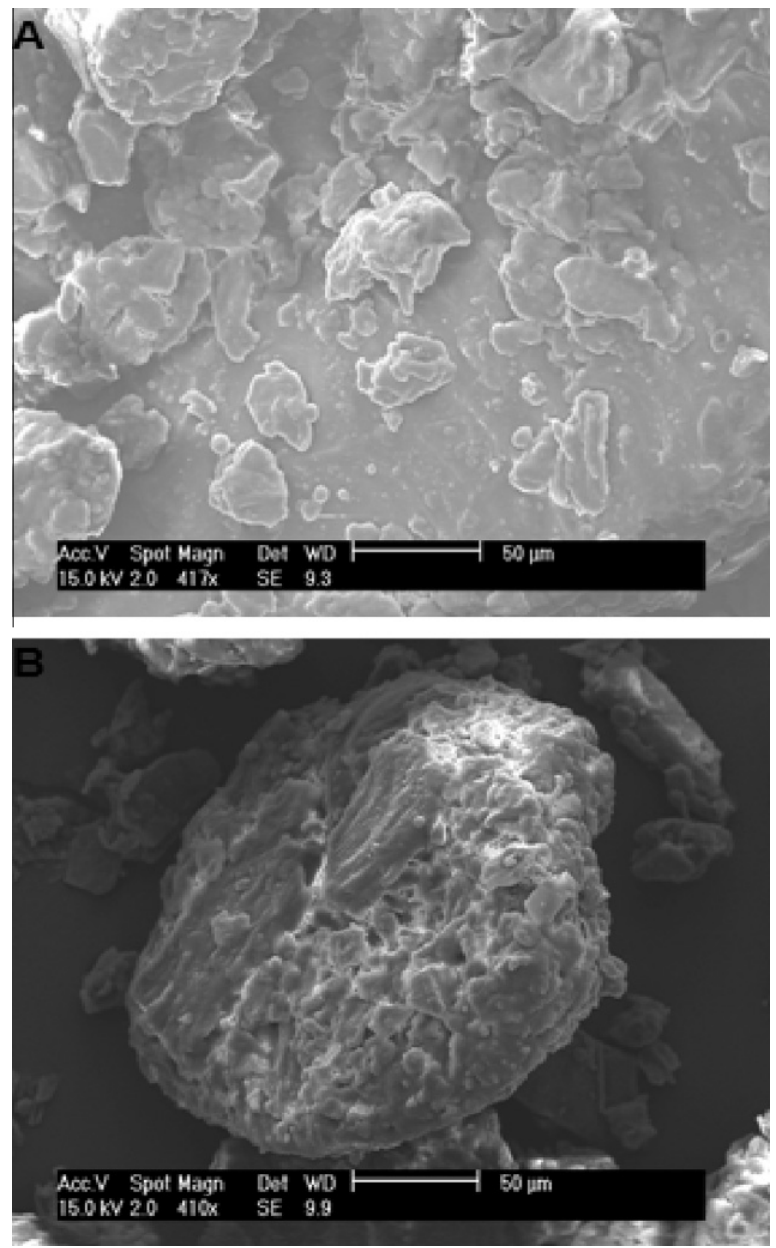

Fig. 3. Scanning electron microscope images of ground coriander seeds $(d=0.5 \mathrm{~mm})$ (A) before supercritical extraction; (B) after supercritical extraction. 
and $2 \mathrm{~kg} / \mathrm{h}$. (experiments 4, 7 and 8 in Table 1 ). Resulting kinetics of extraction are given in Fig. 4.

The results show that increasing the flow rate of $\mathrm{CO}_{2}$ first accel erates the kinetics of extraction. Indeed, external mass transfer coefficient increases with the flow rate of $\mathrm{CO}_{2}$ (Table 2). In addi tion, the driving force (difference between the oil concentration on the seed surface and in the $\mathrm{CO}_{2}$ phase) for external transfer in creases with $\mathrm{CO}_{2}$ flowrate. Hence, time required to reach the pla teau decreased from $160 \mathrm{~min}$ for $1 \mathrm{~kg} / \mathrm{h}$ to $80 \mathrm{~min}$ for $2 \mathrm{~kg} / \mathrm{h}$. Second, the plateau level lowers and the resulting extraction yield decreases significantly from $88 \%$ to $61 \%$ when the flow of $\mathrm{CO}_{2}$ in creases to $2 \mathrm{~kg} / \mathrm{h}$. Considering the subfigure in Fig. 4 where the ex tract amount is presented in function of carbon dioxide use, all the curves initially fit on a straight line whose slope gives an overall solubility of the molecules extracted from coriander seeds. This solubility is then of $3.676 \mathrm{~g} / \mathrm{kg}_{\mathrm{CO}_{2}}$ at $21 \mathrm{MPa}$ and $35^{\circ} \mathrm{C}$. These re sults are classical in extraction and similar to those obtained by Catchpole and Grey (1996). They may be explained by the reduc tion of the contacting time between the carbon dioxide and the bed of coriander during the extraction step. To confirm this result, we have calculated the residence time of carbon dioxide through the bed of coriander, given that the number of passages of $\mathrm{CO}_{2}$ through the bed remains unchanged. This time decreases from $3.96 \mathrm{~min}$ to $1.98 \mathrm{~min}$ when the flow rate rises from $1 \mathrm{~kg} / \mathrm{h}$ to $2 \mathrm{~kg} / \mathrm{h}$. As an additional explanation, it can be suggested that even if carbon dioxide flows faster at the contacting surface of the seeds, thus enhancing external mass transfer, the internal transfer of oils inside the particles is not influenced and becomes increasingly lim iting, thus inducing a decrease of the oil concentration at the con tacting surface of the seeds. The increase of the Biot number with the flow rate of $\mathrm{CO}_{2}$ strengthens this suggestion (Table 2). Hence, $1 \mathrm{~kg} / \mathrm{h}$ has been chosen for the following experiments.

\subsubsection{Influence of pressure}

The influence of two different pressures, 10 and $21 \mathrm{MPa}$, on the extraction ratio has been considered at $35^{\circ} \mathrm{C}$, for a mean particle size of ground seeds of $0.5 \mathrm{~mm}$ and a supercritical fluid flow rate of $1 \mathrm{~kg} / \mathrm{h}$. This corresponds to experiments 1 and 2 in Table 1 and extraction kinetic is given in Fig. 5.

Statistical analysis (Table 2) and the extraction curves (Fig. 5) show that the increase of pressure enhances the kinetics and greatly reduces the extraction time while increasing significantly the extraction efficiency. Indeed, as the pressure increases from 10 to $21 \mathrm{MPa}$, the extraction ratio rises from $23 \%$ to $85 \%$ and the time needed to achieve the extraction decreases from more than $300 \mathrm{~min}$ to $200 \mathrm{~min}$. These effects could be attributed to the in

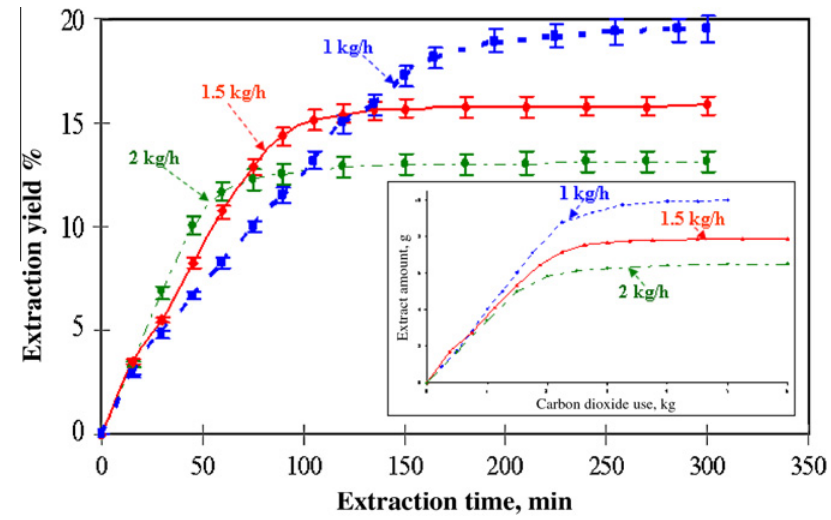

Fig. 4. Effect of the $\mathrm{CO}_{2}$ flow rate on the extraction yield in function of time for $P=21 \mathrm{MPa}, T=35^{\circ} \mathrm{C}$ and $d=0.3 \mathrm{~mm}$.

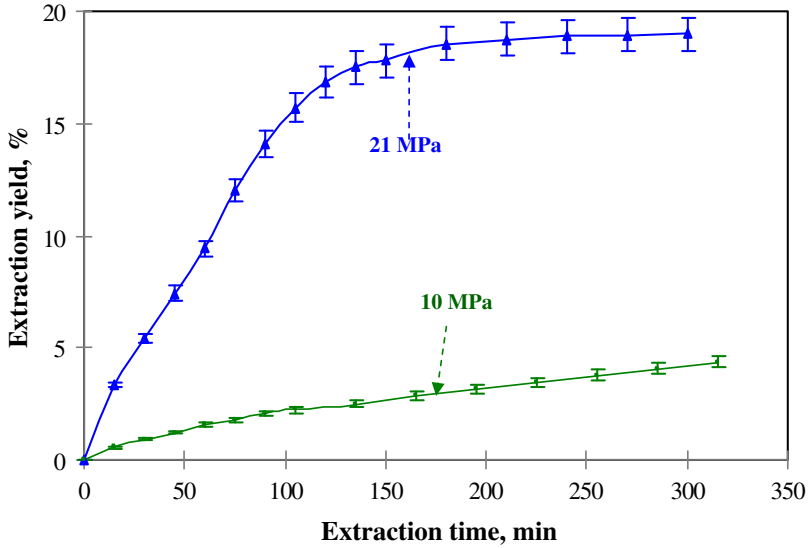

Fig. 5. Effect of pressure on the extraction yield in function of time for $T=35^{\circ} \mathrm{C}$, $Q=1 \mathrm{~kg} / \mathrm{h}$ and $d=0.5 \mathrm{~mm}$.

crease of the $\mathrm{CO}_{2}$ density, related to the solvent power and then the solubility of the oil. Similar effect of pressure on extraction has been observed by several research teams who have worked on the extraction of oil seeds by supercritical $\mathrm{CO}_{2}$ (Bandoni et al., 1998; Catchpole and Grey, 1996; Machmudah et al., 2008; Grosso et al., 2008; Illés et al., 2000; Temelli, 2009). In addition, to go fur ther in the comprehension of the extraction kinetics, diffusivities of the solute transferred into the supercritical fluid have been calcu lated. We have found that values of diffusivities at a pressure of $10 \mathrm{MPa}$ and $21 \mathrm{MPa}$ were respectively $0.5 \times 10^{13} \mathrm{~m}^{2} / \mathrm{s}$ and $10^{13} \mathrm{~m}^{2} / \mathrm{s}$.

As for the oil composition, when the pressure increases from $10 \mathrm{MPa}$ to $21 \mathrm{MPa}$, the amount of extracted EO remains the same while the amount of VO extracted increases significantly. There fore, the extraction of EO can then be performed at a moderate pressure of $10 \mathrm{MPa}$ while the VO extraction requires higher pres sures. To confirm this, an extraction test in two steps has been per formed in order to extract first the EO and second the VO at two different pressures ( $8 \mathrm{MPa}$ and $21 \mathrm{MPa}$ ) and thus at two different $\mathrm{CO}_{2}$ densities (Fig. 6):

First Step: $8 \mathrm{MPa}$ and $35{ }^{\circ} \mathrm{C}$, which corresponds to a $\mathrm{CO}_{2}$ density of $419.9 \mathrm{~kg} / \mathrm{m}^{3}$.

Second Step: $21 \mathrm{MPa}$ and $35{ }^{\circ} \mathrm{C}$, which corresponds to a $\mathrm{CO}_{2}$ density of $873.6 \mathrm{~kg} / \mathrm{m}^{3}$.

The $\mathrm{CO}_{2}$ densities have been obtained from the equation of state proposed by Span and Wagner (1996).

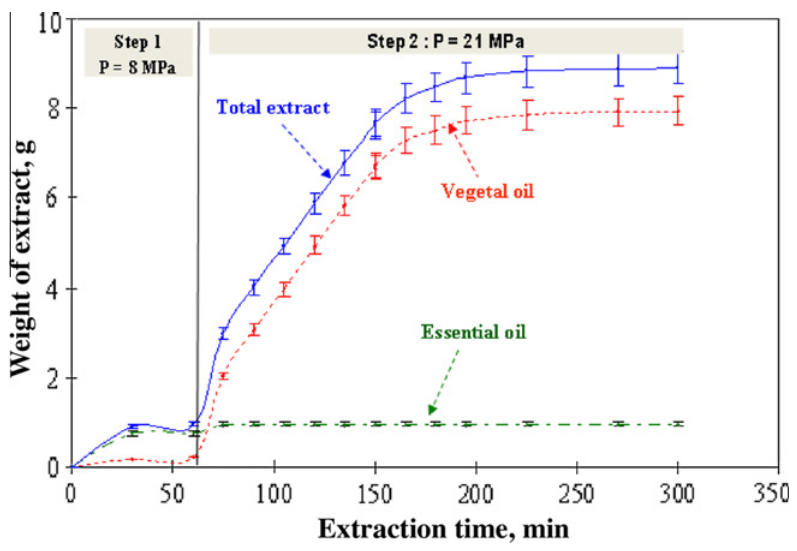

Fig. 6. Effect of pressure on the selectivity of the two-step extraction process. 
Fig. 6 shows that during the first extraction step ( $8 \mathrm{MPa}$ ), only the EO and water were recovered while in the second step (21 MPa) only VO was recovered. These results confirm our previ ous comments about the effect of pressure and subsequent density of $\mathrm{CO}_{2}$ on the selectivity of the extraction of both oils. As a conclu sion, this two step extraction is then a selective process that is effective and rather easy to implement.

\subsubsection{Influence of temperature}

The influence of the extraction temperature $\left(35^{\circ} \mathrm{C}, 45^{\circ} \mathrm{C}\right.$ and $55^{\circ} \mathrm{C}$ ) has been studied using the following extraction conditions of pressure, flow rate, and particle size: $21 \mathrm{MPa}, 1 \mathrm{~kg} / \mathrm{h}$ and $0.3 \mathrm{~mm}$. It corresponds to experiments 4,5 and 6 in Table 1 . The resulting extraction kinetic is presented in Fig. 7.

The temperature does not exert a significant effect on the extraction ratio. Indeed, it increases from $88 \%$ to $90 \%$ as tempera ture rises from $35{ }^{\circ} \mathrm{C}$ to $55^{\circ} \mathrm{C}$ but this increase proved to be insig nificant at the $5 \%$ error level. This limited effect of the temperature could be explained by two opposite phenomena that occur simul taneously. The increase of temperature induces a decrease of the $\mathrm{CO}_{2}$ density and of its solvent power, tending to decrease the yield of extraction. In the same time, the rise in temperature induces an increase of the solute vapor pressure and therefore of its solubility in the supercritical fluid, tending to increase the extraction yield. These two opposite effects are competing. It has been often ob served in previous works that the effect of vapor pressure prevails and the result is a positive effect of temperature on the extraction ratio (Brunner, 1994; Grosso et al., 2008). In this case, the balance of both effects appears without significant impact. In addition, temperature does not have significant effect on the extraction kinetics (Fig. 7). Therefore, on a process point of view, the temper ature of $35^{\circ} \mathrm{C}$ is a satisfying compromise.

\subsubsection{Influence of density of $\mathrm{CO}_{2}$}

The combined effect of pressure and temperature resulting when changing solvent density is presented in Fig. 8. Five extrac tion tests were performed for five different values of $\mathrm{CO}_{2}$ density and under the same conditions of $\mathrm{CO}_{2}$ flow rate. They correspond to experiments 2, 4, 5, 6 and 10a in Table 1 .

The results show that the extraction ratio drastically increases with density, which goes up from $2 \%$ for a density of $419 \mathrm{~kg} / \mathrm{m}^{3}$ (when only EO is extracted) to $90 \%$ for a density value around $800 \mathrm{~kg} / \mathrm{m}^{3}$. This significant effect of density on the extraction ratio confirms the prominent effect of the solvent power of $\mathrm{CO}_{2}$ and hence of the solubility level of oils in carbon dioxide, which can

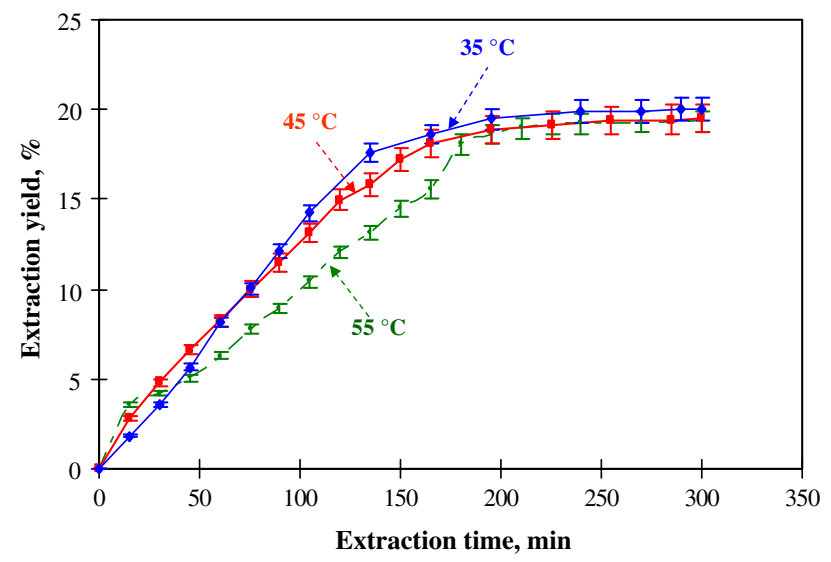

Fig. 7. Effect of temperature on the extraction yield versus time for $P=21 \mathrm{MPa}$, $Q=1 \mathrm{~kg} / \mathrm{h}$ and $d=0.3 \mathrm{~mm}$.

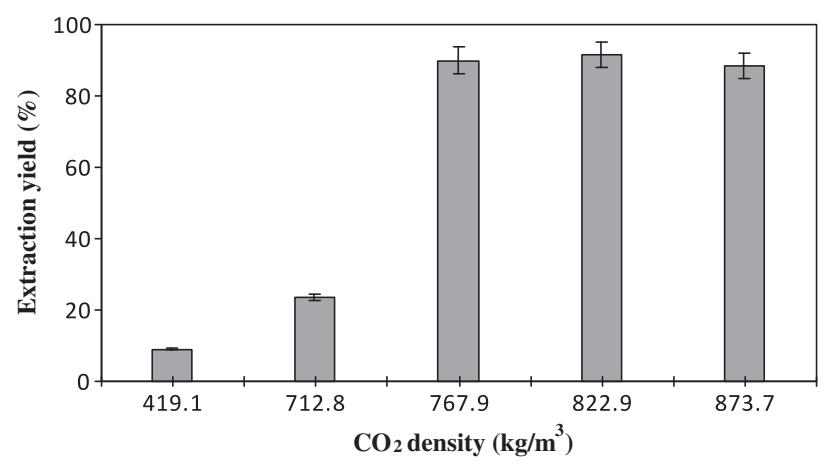

Fig. 8. Effect of the $\mathrm{CO}_{2}$ density on the extraction ratio for $Q=1 \mathrm{~kg} / \mathrm{h}$.

be tuned mainly by varying pressure and, in a minor way, by changing temperature. In the same context, Temelli (2009) has shown that the solubility of triglycerides in carbon dioxide greatly increases when the $\mathrm{CO}_{2}$ density rises for a constant value of tem perature. For instance, at $50{ }^{\circ} \mathrm{C}$, when the $\mathrm{CO}_{2}$ density increases from $492 \mathrm{~kg} / \mathrm{m}^{3}$ to $897 \mathrm{~kg} / \mathrm{m}^{3}$, triolein solubility goes up from $6.7 \times 10^{3} \mathrm{~g} / \mathrm{L}$ to $7.4 \mathrm{~g} / \mathrm{L}$.

3.3. Effect of the operating conditions on the composition of vegetal oil and essential oil

The VO and the EO obtained were analyzed and their chemical composition was compared with those obtained respectively by Soxhlet and steam distillation using the same particle size fraction (Tables 3 and 4).

\subsubsection{Vegetal oil composition}

Different samples of VO are analyzed by gas chromatography and their fatty acid composition is shown in Table 3.

VO of coriander is very rich in unsaturated fatty acids: about 95\% in mass are unsaturated, splitted in $80 \%$ monounsaturated (mainly petroselinic acid, oleic acid palmitoleic acid and gadoleic acid) and $15 \%$ polyunsaturated (mainly linoleic acid and linolenic acid). The major fatty acid is petroselinic acid (above 70\%). These values are similar to the results found by Msaada et al. (2009a,b). It is noteworthy that operating conditions (T; P, Q and d) have no major effect on the fatty acid composition of coriander VO (exper iments 18 in Table 3). Comparing experiment 1 and 9 (Table 3 ) shows that, as can be expected, previous drying of the seeds at $70{ }^{\circ} \mathrm{C}$ has no influence on the fatty acid composition.

Comparison between the compositions of the VO obtained by organic solvent extraction (experiment Soxhlet in Table 3) and by supercritical $\mathrm{CO}_{2}$ shows that both fatty acids profiles are similar. However, ten fatty acids have been identified from oil obtained by supercritical $\mathrm{CO}_{2}$, while only nine have been identified from the oil extracted by Soxhlet. The latter does not contain arachidic acid but it is richer in gadoleic acid ( $0.39 \%$ compared to an average value of $0.11 \%$ in supercritical fluid extraction) and in oleic acid (6.69\% compared to an average value of $5.77 \%$ in supercritical fluid extraction).

\subsubsection{Essential oil composition}

The composition of the coriander essential oil obtained by the supercritical extraction and the one obtained by steam distillation has been determined. The essential oil extracted from coriander seeds that were previously dried has also been analyzed (Table 4).

Results show that essential oil extracted by supercritical $\mathrm{CO}_{2}$ contains 29 compounds, whereas 35 compounds have been identi fied in the case of extraction by steam distillation. This could be 
Table 3

Fatty acid composition of different samples of vegetal oil.

\begin{tabular}{|c|c|c|c|c|c|c|c|c|c|c|}
\hline \multicolumn{11}{|l|}{ Experiment } \\
\hline Fatty acid (mass percent) & 1 & 2 & 3 & 4 & 5 & 6 & 7 & 8 & 9 & Soxhlet \\
\hline \multicolumn{11}{|l|}{ Saturated fatty acids (SFA) } \\
\hline Myrestic acid (C14:0) & 0.12 & 0.06 & 0.04 & 0.10 & 0.11 & 0.04 & 0.04 & 0.11 & 0.11 & 0.08 \\
\hline Palmitic acid (C16:0) & 3.73 & 4.42 & 3.70 & 3.76 & 3.67 & 3.77 & 3.45 & 3.68 & 3.69 & 3.90 \\
\hline Stearic acid (C18:0) & 1.29 & 0.97 & 0.94 & 1.15 & 1.03 & 0.94 & 0.96 & 1.14 & 0.95 & 0.97 \\
\hline Arachidic acid (C20:0) & 0.16 & 0.18 & 0.16 & 0.14 & 0.14 & 0.16 & 0.15 & 0.14 & 0.13 & 0.00 \\
\hline Total SFA & 5.29 & 5.64 & 4.83 & 5.15 & 4.95 & 4.90 & 4.59 & 5.08 & 4.88 & 4.95 \\
\hline \multicolumn{11}{|c|}{ Monounsaturated fatty acids (MFA) } \\
\hline Palmitoleic acid $\left(\mathrm{C} 16: 1 \Delta^{9}\right)$ & 0.18 & 0.25 & 0.20 & 0.18 & 0.19 & 0.20 & 0.18 & 0.17 & 0.20 & 0.20 \\
\hline Petroselinic acid $\left(\mathrm{C} 18: 1 \Delta^{6}\right)$ & 73.9 & 72.3 & 73.7 & 74.7 & 75.0 & 73.7 & 75.3 & 74.7 & 74.2 & 72.99 \\
\hline Oleic acid $\left(\mathrm{C} 18: 1 \Delta^{9}\right)$ & 5.99 & 6.09 & 6.22 & 5.32 & 5.14 & 6.03 & 5.81 & 5.39 & 5.94 & 6.69 \\
\hline Gadoleic acid $\left(\mathrm{C} 20: 1 \Delta^{11}\right)$ & 0.12 & 0.17 & 0.10 & 0.09 & 0.10 & 0.13 & 0.08 & 0.09 & 0.09 & 0.39 \\
\hline Total MFA & 80.2 & 78.8 & 80.2 & 80.3 & 80.4 & 80.0 & 81.4 & 80.4 & 80.42 & 80.27 \\
\hline \multicolumn{11}{|l|}{ Polyunsaturated fatty acids (PFA) } \\
\hline Linoleic acid $\left(\mathrm{C} 18: 2 \Delta^{9,12}\right)$ & 14.3 & 15.3 & 14.6 & 14.3 & 14.4 & 14.7 & 13.7 & 14.3 & 14.5 & 14.60 \\
\hline Linolenic acid $\left(\mathrm{C} 18: 3 \Delta^{9,12,15}\right)$ & 0.16 & 0.22 & 0.26 & 0.16 & 0.16 & 0.25 & 0.25 & 0.16 & 0.16 & 0.18 \\
\hline Total PFA & 14.5 & 15.5 & 14.9 & 14.5 & 14.5 & 15.0 & 14.0 & 14.4 & 14.7 & 14.78 \\
\hline Total & 100 & 100 & 100 & 100 & 100 & 100 & 100 & 100 & 100 & 100 \\
\hline
\end{tabular}

attributed to hydrolysis and/or oxidation of some compounds during the extraction by steam distillation. For instance, linalool

Table 4

Chemical composition of coriander essential oil.

\begin{tabular}{|c|c|c|c|}
\hline \multicolumn{4}{|l|}{ Experiment } \\
\hline $\begin{array}{l}\text { Component } \\
\text { (mass percent) }\end{array}$ & $\begin{array}{l}\text { Steam } \\
\text { distillation } \\
\text { extraction }\end{array}$ & $\begin{array}{l}\text { Supercritical } \\
\text { extraction } \\
(21 \mathrm{MPa} \text {, } \\
35^{\circ} \mathrm{C}, 1 \mathrm{~kg} / \mathrm{h} \\
\text { and } \\
d=0.3 \mathrm{~mm})\end{array}$ & $\begin{array}{l}\text { Supercritical } \\
\text { extraction } \\
\text { from dried } \\
\text { seeds }\end{array}$ \\
\hline$\alpha$-Pinene & 3.78 & 0.44 & 0.55 \\
\hline Camphene & 0.44 & 0.10 & \\
\hline$\alpha$-Thujene & & 0.37 & \\
\hline Myrcene & 1.02 & 0.27 & 0.28 \\
\hline$\beta$-Pinene & 0.02 & & \\
\hline$\alpha$-Terpinene & 2.09 & 1.63 & 4.97 \\
\hline p-Cymene & 2.64 & 0.63 & 0.95 \\
\hline Limonene & 0.02 & 3.12 & 1.53 \\
\hline \$3-Carene & 0.03 & 2.39 & \\
\hline$\gamma$-Terpinene & 9.88 & 2.77 & 0.98 \\
\hline Sabinene & 0.06 & 0.34 & 0.17 \\
\hline 1,8-Cineole & 0.06 & 0.18 & \\
\hline Cis-linalool oxide (furanoid) & 0.04 & & \\
\hline $\begin{array}{l}\text { Trans-linalool oxide } \\
\text { (furanoid) }\end{array}$ & 0.75 & & \\
\hline Linalool & 57.03 & 66.33 & 74.28 \\
\hline Camphor & 5.13 & 3.34 & 3.96 \\
\hline Menthol & 0.03 & 0.13 & \\
\hline Borneol & 0.12 & 0.35 & 0.29 \\
\hline Terpinene-4-ol & 0.34 & 0.95 & 0.22 \\
\hline$\alpha$-Terpineol & 0.52 & 0.33 & \\
\hline p-Cymene-8-ol & 0.37 & 0.12 & \\
\hline Cis-dihydrocarvone & 0.14 & 0.14 & \\
\hline Carvone & 0.15 & 0.30 & \\
\hline Linalyl acetate & 5.36 & 2.37 & 0.80 \\
\hline Nerol & 0.06 & 0.12 & 0.20 \\
\hline$\beta$-Citronellol & 0.24 & 0.58 & \\
\hline Geraniol & 0.15 & 0.13 & \\
\hline Neral & 0.06 & 0.06 & \\
\hline Thymol & 0.04 & & \\
\hline Anethole & 0.05 & & \\
\hline Geranial & 0.03 & & \\
\hline Carvacrol & 0.03 & & \\
\hline Eugenol & 0.07 & 0.11 & \\
\hline Geranyl acetate & 5.39 & 2.16 & 3.98 \\
\hline Caryphyllene & 0.33 & 0.20 & 0.27 \\
\hline Humulene & 0.05 & 0.45 & 0.81 \\
\hline
\end{tabular}

This supercritical extraction experiment was performed at $P=21 \mathrm{MPa}, T=35^{\circ} \mathrm{C}$, $Q=1 \mathrm{~kg} / \mathrm{h}$ and $d=0.3 \mathrm{~mm}$, from seeds previously dried at $70{ }^{\circ} \mathrm{C}$ and $60 \mathrm{kPa}$ for $24 \mathrm{~h}$. extracted by steam distillation exists in three forms, which are respectively linalool, cis linalool oxide and trans linalool oxide. In addition, essential oil extracted by supercritical $\mathrm{CO}_{2}$ is richer in linalool and in limonene (66\% and 3\%) than that obtained by hydrodistillation (57\% and $0.02 \%$ ). At last, a previous drying of cori ander seeds before extraction affects the quality of the essential oil. Indeed, only 16 compounds were identified. This could be ex plained by the evaporation of some of the volatile compounds, such as camphene, $\alpha$ thujene, 1,8 cineole, menthol, carvone..., dur ing drying. This may also explain the lower extraction ratio ob tained for experiment 9 when compared to experiment 1 (Table 2).

\section{Conclusion}

Coriander seeds were extracted using supercritical carbon diox ide to obtain selectively vegetal oil and essential oil. A process in four steps has been set up. A range of pressures, temperatures, par ticle diameters and carbon dioxide flow rates were investigated in order to elucidate their effect on the extraction yield and the com position of the extract. Pressure, particle size and flow rate have re vealed to have a significant influence on the extraction yield while they have no major effect on the composition of the extracted oils. The vegetal oil obtained is rich in petroselinic acid and its fatty acid composition is similar to that obtained by Soxhlet. The essential oil extracted is undamaged compared to steam distillation extraction and supercritical extraction from dried coriander seeds.

As for the process proposed in this work, the selective extrac tion of vegetal and essential oils can be conducted according two ways: either extracting selectively or fractionating oils after extraction. The first way consists in extracting both oils at the same time at a pressure of $21 \mathrm{MPa}$ and in fractionating them afterwards using two consecutive separators with adequate temperature and pressure conditions. It has been found that $21 \mathrm{MPa}$ and $35^{\circ} \mathrm{C}$ as extraction conditions together with a supercritical fluid flow rate of $1 \mathrm{~kg} / \mathrm{h}$ and a mean size of $0.5 \mathrm{~mm}$ for the ground seeds are the best conditions tested to extract oils of good quality and to maximize the extraction ratio (90\%). This study has also shown that $7 \mathrm{MPa}$ and $30^{\circ} \mathrm{C}$ in separator 1 and $4 \mathrm{MPa}$ and $10^{\circ} \mathrm{C}$ in separator 2 allows recovering respectively the $\mathrm{VO}$ and EO. The sec ond method is a new selective process in two consecutive extrac tion steps. The first extraction step is performed at $8 \mathrm{MPa}$ and $35^{\circ} \mathrm{C}$ in order to extract only the EO. Then, $21 \mathrm{MPa}$ and $35^{\circ} \mathrm{C}$ are the convenient extraction conditions for the second step which allows extracting VO. 


\section{Acknowledgments}

This work is part of a research project financed with the help of the Région Midi Pyrénées, France, which is gratefully acknowl edged. The CNRS (France) and the DGRS (Tunisia) contributed also to finance this work through their joint program of international cooperation. The authors also thank the team from LCA ENSIACET Toulouse, France and especially Mr. Thierry Talou for the chro matographic analyses.

\section{References}

Aluko, R.E., McIntosh, T., Reaney, M., 2001. Comparative study of the emulsifying and foaming properties of defatted coriander (Coriandrum sativum) seed flour and protein concentrate. Food Research International 34 (8), 733-738.

Anitescu, G., Doneanu, C., Radulescu, V., 1997. Isolation of coriander oil: comparison between steam distillation and supercritical $\mathrm{CO}_{2}$ extraction. Flavour and Fragrance Journal 12 (3), 173-176.

Bandoni, A.L., Mizrahi, I., Juarez, M.A., 1998. Composition and quality of the essential oil of coriander (Coriandrum sativum L.) from Argentina (average analysis of 6 oils). Journal of Essential Oil Research 10, 581-584.

Boutin, O., Badens, E., 2009. Extraction from oleaginous seeds using supercritical $\mathrm{CO}_{2}$ : experimental design and products quality. Journal of Food Engineering 92 (4), 396-402

Brunner, G., 1994. Gaz extraction. In: Baumgartel, H., Frank, U. (Eds.), Topics in Physical Chemistry. Springer, New York, pp. 3-163.

Brunner, G., 2005. Supercritical fluids: technology and application to food processing. Journal of Food Engineering 67 (1-2), 21-33.

Burdok, G.A., Carabin, L.G., 2009. Safety assessment of coriander (Coriandrum sativum L.) essential oil as a good ingredient. Food and Chemical Toxicology 47 (1), 22-34.

Catchpole, O.J., Grey, J.B., 1996. Near-critical extraction of sage, celery, and coriander seed. Journal of Supercritical Fluids 9 (4), 273-279.

Chithra, V., Leelamma, S., 2000. Coriandrum sativum - effect on lipid metabolism in 1,2-dimethyl hydrazine induced colon cancer. Journal of Ethnopharmacology 71 (3), 457-463.

Donelian, A., Carlson, L.H.C., Lopes, T.J., Machado, R.A.F., 2009. Comparison of extraction of patchouli (Pogostemon cablin) essential oil with supercritical $\mathrm{CO}_{2}$ and by steam distillation. Journal of Supercritical Fluids 48 (1) 15-20.

Eyres, G., Dufour, J.P., Hallifax, G., Sotheeswaran, S., Marriott, P.J., 2005 Identification of character-impact odorants in coriander and wild coriander leaves using gas chromatography-olfactometry (GCO) and comprehensive twodimensional gas chromatography-time-of-flight mass spectrometry (GOC $\times$ GC-TOFMS). Journal of Separation Science 28 (9-10), 1061-1074.
Gallagher, A.M., Flatt, P.R., Duffy, G., Abdel-Wahab, Y.H.A., 2003. The effects of traditional antidiabetic plants on in vitro glucose diffusion. Nutrition Research 23 (3), 413-424.

Goto, M., Sato, M., Hirose, T., 1993. Extraction of peppermint oil by supercritical carbon dioxide. Journal of Chemical Engineering 26 (4), 401-407.

Goto, M., Hirose, T., McCoy, B.J., 1994. Continuous-mixture model of extraction processes. Journal of Supercritical Fluids 7 (1), 61-66.

Grosso, C., Ferraro, V., Figueiredo, A.C., Barroso, J.G., Coelho, J.A., Palavra, A.M., 2008. Supercritical carbon dioxide extraction of volatile oil from Italian coriander seeds. Food Chemistry 111 (1), 197-203.

Illés, V., Daood, H.G., Perneczki, S., Szokonya, L., Then, M., 2000. Extraction of coriander seed oil by $\mathrm{CO}_{2}$ and propane at super- and subcritical conditions. Journal of Supercritical Fluids 17 (2), 177-186.

Jabeen, Q., Bashir, S., Lyoussi, B., Gilani, A.H., 2009. Coriander fruit exhibits gut modulatory, blood pressure lowering and diuretic activities. Journal of Ethnopharmacology 122 (1), 123-130.

Kubo, I., Fujita, K., Kubo, A., Nihei, K., Ogura, T., 2004. Antibacterial activity of coriander volatile compounds against Salmonella choleraesuis. Journal of Agricultural and Food Chemistry 52 (11), 3329-3332.

Machmudah, S., Kondo, M., Sasaki, M., Goto, M., Munemasa, J., Yamagata, M., 2008. Pressure effect in supercritical $\mathrm{CO}_{2}$ extraction of plant seeds. Journal of Supercritical Fluids 44, 301-307.

Matasyoh, J.C., Maiyo, Z.C., Ngure, R.M., Chepkorir, R., 2009. Chemical composition and antimicrobial activity of the essential oil of Coriandrum sativum. Food Chemistry $113(2), 526-529$.

Mohamed, R.S., Mansoori, G.A., 2002. The use of supercritical fluid extraction technology in food processing. Food Technology Magazine 20, 134-139.

Msaada, K., Hosni, K., Ben Taarit, M. Chahed, T., Kchouk, M.E., Marzouk, B., 2007. Changes on essential oil composition of coriander (Coriandrum sativum L.) fruits during three stages of maturity. Food Chemistry 102 (4), 1131-1134.

Msaada, K., Hosni, K., Ben Taarit, M., Chahed, T., Hammami, M., Marzouk, B., 2009a. Changes in fatty acid composition of coriander (Coriandrum sativum L.) fruit during maturation. Industrial Crops and Products 29 (2-3), 269-274.

Msaada, K., Hosni, K, Ben Taarit, M. Chahed, T., Hammami, M., Marzouk, B., 2009b. Effects of growing region and maturity stages on oil yield and fatty acid composition of coriander (Coriandrum sativum L.) fruit. Scientia Horticulturae 120 (4), 525-531.

Perrut, M., Clavier, J.Y., 2003. Supercritical fluid formulation: process choice and scale-up. Industrial and Engineering Chemistry Research 42 (25), 6375-6383.

Span, R., Wagner, W., 1996. A new equation of state for carbon dioxide covering the fluid region from the triple-point temperature to $1100 \mathrm{~K}$ at pressures up to $800 \mathrm{MPa}$. Journal of Physical and Chemical Reference Data 25 (6), 15091596.

Temelli, F., 2009. Perspectives on supercritical fluid processing of fats and oils. The Journal of Supercritical Fluids 47 (3), 583-590.

Wangensteen, H., Samuelsen, A.B., Malterud, K.E., 2004. Antioxidant activity in extracts from coriander. Food Chemistry 88 (2), 293-297. 